\title{
Persistent isolated cough in childhood
}

\author{
Sri Lanka Journal of Child Health, 2004; 33: 95-6
}

(Key words: persistent isolated cough, child, PIC)

'Normal' children, even in the absence of a respiratory tract infection (RTI), have a mean number of 11 cough episodes per 24 hours ${ }^{1}$. Presence of an upper RTI is associated with increased cough but in most cases this is of less than 2 weeks duration. However, in some of them the cough persists for more than 3 weeks possibly due to increased cough receptor sensitivity ${ }^{2}$. Although the cough can persist for months, it is usually selflimiting ${ }^{3}$.

Persistent isolated cough (PIC) is defined as a nonproductive cough of at least 3 weeks duration in the absence of identifiable respiratory disease or disease of the upper airway ${ }^{4}$. It is common for the cough to be present mainly at night. Other terms used interchangeably with PIC include non-specific cough, persistent cough, isolated cough, recurrent cough and chronic cough ${ }^{2,5,6}$. A productive cough is always abnormal and requires further investigation. There are several causes of a productive cough such as bronchiectasis, recurrent milk and food aspiration, cardiac disease, inhaled foreign body and cystic fibrosis ${ }^{4}$.

The term 'cough variant asthma' was first used to describe those patients who presented with cough as a single manifestation of their asthma and who seemed to respond to bronchodilators or short-term corticosteroid medication ${ }^{7}$. It has been suggested that asthma in children was being under-diagnosed because of failure to recognize the entity 'cough-variant asthma' ${ }^{8}$. On the other hand, if children with persistent cough are not a subset of asthma, then treating them as such may be inappropriate. In fact, recent British asthma guidelines state "criteria for defining asthma in the presence of chronic or recurrent cough have not been adequately defined"". Let us consider the evidence available in this regard.

No correlation has been shown between cough severity and airway calibre ${ }^{10}$. Furthermore, sites for eliciting cough are confined to structures innervated by the vagus in contrast to sites inducing bron-choconstriction ${ }^{11}$. Therefore, pathways for cough and bronchoconstriction are distinctly different ${ }^{2}$. The inflammatory cell profile of bronchoalveolar lavage fluid of children with chronic cough is similar to that of non-asthmatic children. Asthma is associated with a high median ratio of eosinophils to neutrophils ${ }^{12}$.

An Australian study showed that children with persistent cough in the community do not have features in common with asthma $1^{3}$. This agrees with recent cross-sectional studies in school children that show that persistent cough in absence of wheeze differs from classical asthma and resembles the asymptomatic population more closely having less morbidity and atopy compared to those with wheeze ${ }^{14}$.

Lung function tests in preschool children with isolated cough have shown that coughers do not differ significantly from controls in their lung function ${ }^{12}$.

A prospective, longitudinal $\operatorname{study}^{14}$ has shown that children with recurrent cough and no wheeze did not differ from those who were asymptomatic in terms of their immunoglobulin E levels, skin prick tests and percentage decline in lung function following cold air challenge. In contrast, children with both cough and wheeze had more atopy and a greater decline in lung function with cold air challenge.

If PIC is a variant of asthma, a response to therapy with anti-asthma medication would be expected. However, it has been shown that children with recurrent or persistent cough do not benefit from bron-chodilators ${ }^{3}$. Of two studies looking at the effect of inhaled corticosteroids in children with PIC ${ }^{5,15}$, only one, which used very high doses, demonstrated modest benefit ${ }^{15}$. However, it was shown that those receiving placebo improved after 2 weeks as well ${ }^{15}$. This suggests that the natural history of PIC is that it gets better and prescribing medication is of no benefit, at least in the first instance.

In summary, available evidence to date indicates that PIC is a separate entity from asthma. In the absence of other symptoms or risk factors, cough alone is a poor marker of asthma.

In children who have been immunised with triple vaccine pertussis may occur in a milder atypical form as a persistent cough due to lingering tracheo-bronchitis ${ }^{16}$. The cough may be paroxysmal and may be followed by vomiting. There is no whoop. A clue to the diagnosis is the presence of an absolute lymphocytosis which is not a feature of adenoviral infections which may give rise to an otherwise similar picture ${ }^{16}$. 
The link between gastro-oesophageal reflux (GOR) and persistent cough remains debatable. It has been shown that treatment of GOR fails to relieve the cough although the GOR may improve ${ }^{17}$. This is therefore an unlikely cause of persistent cough.

The relationship between persistent cough and postnasal drip is controversial as there are no cough receptors in the pharynx or post-nasal space ${ }^{18}$.

\section{References}

1. Munyard P, Bush A. How much coughing is normal? Arch Dis Child 1996; 74: 531-4.

2. Chang A B. Cough, cough receptors and asthma in children. Pediatr Pulmonol 1999; 28: 69-70.

3. Chang A B, Phelan P D, Carlin J B, Sawyer S M, Robertson C F. A randomized, placebo controlled trial of inhaled salbutamol and beclomethasone for recurrent cough. Arch Dis Child 1998; 70: 6-11.

4. Saglani S, McKenzie S A. The management of persistent isolated cough in childhood. Current Paediatrics 2002; 12: 1-6.

5. Chang A B, Robertson C F. Cough in children. Med $J$ Aust 2000; 172: 122-5.

6. McKenzie S A, Bridge P D, Healy M J R. Airway resistance and atopy in preschool children with wheeze and cough. Eur Resp J 2000; 15: 833-8.

7. Glauster F L. Variant asthma. Ann Allergy 1972; 30: $457-9$.

8. Hannaway P J, Hopper D. Cough variant asthma in children. JAMA 1982; 247: 206-8.

9. British Thoracic Society. National Asthma Campaign, Royal College of Physicians of London, et al. British guidelines on asthma management: review and position statement. Thorax 1997; 52 (suppl. 1).
10. Hoskyns E W, Beardsmore C S, Simpson H. Chronic night cough and asthma severity in children with stable asthma. Eur J Pediatr 1995; 154: $320-5$.

11. Widdicombe J G. Sensory neurophysiology of the cough reflex. J Allergy Clin Immunol 1996; 98: 8490 .

12. Marguet C, Jouen-Boeder F, Dean T P, Warner J O. Bronchoalveolar cell profiles in children with asthma, infantile wheeze, chronic cough or cystic fibrosis. Am J Respir Crit Care Med 1999; 159: 1533-40.

13. Faniran A O, Peat J K, Woolcock A J. Persistent cough: is it asthma? Arch Dis Child 1998; 79: 4114.

14. Wright A L, Holberg C J, Morgan W J, Taussig L $\mathrm{M}$ et al. Recurrent cough in childhood and its relation to asthma. Am J Respir Crit Care Med 1996; 153: 1259-65.

15. Davies M J, Fuller P, Picciotto A, McKenzie S A. Persistent nocturnal cough: randomized controlled trial of high dose inhaled corticosteroids. Arch Dis Child 1999; 81: 38-44.

16. Mortimer E A. Pertussis and its prevention: A family affair. J Infect Dis 1990; 161: 473.

17. Dordal M T, Baltazar I A, Roca I. Nocturnal spasmodic cough in the infant. Evolution after antireflux treatment. Allergie Immunol 1994; 26: 53-8.

18. Lalloo UG, Barnes PJ, Chung FK. Pathophysiology and clinical presentation of cough. J Allergy Clin Immunol 1996; 98: 591-7.

\section{G N Lucas}

Joint Editor 
